\title{
Effect of Hollowing Ratio on the Behavior of Hollow Self-Com- pacting Reinforced Concrete Slender Column Under Eccentric Loading
}

\author{
${ }^{1}$ Ihsan A. S. Al- Shaarbaf, ${ }^{2}$ Mohammed J. H. Al-zubaidi, ${ }^{3}$ Emad A. A. Al- Zaidy \\ ${ }^{l}$ Civil engineering department- Al- Essra college \\ ${ }^{2}$ University of Technology-Civil engineering department \\ ${ }^{3}$ Mazaya University College-Civil engineering department \\ *Corresponding author E-mail:emadabood125@gmail.com
}

\begin{abstract}
In this research the behavior of reinforced concrete slender columns with longitudinal hole under axial compression load and uniaxial bending is investigated. The paper includes testing of ten slender columns with dimensions $\left(150 \times{ }_{150} \times 1300\right.$ mm). The investigation deals with the effect of using different diameters of column hole on the values of the load carrying capacity and cracking loads, mid-height lateral deflection and longitudinal shortening of the columns. Five diameters for the column holes were considered $(0,25.4,38.1,50.8$, and 76.2)mm. Test results have showed that when the holes were located at the center of the column cross-section and the column was loaded with high load eccentricity, the effect of hollowing ratio on load capacity is insignificant. For hollowing ratios used in this study $(0 \%, 2.3 \%, 5.1 \%, 9 \%$ and $20.3 \%)$, the ultimate load is decreased by $(0 \%, 0.28 \%, 1.03 \%, 3.28 \%$ and $6.48 \%)$ respectively. The effect of hollowing ratio on columns loaded with small eccentricity of $50 \mathrm{~mm}(\mathrm{e} / \mathrm{h}=.33)$ is greater than the effect of hollow ratio of columns with $150 \mathrm{~mm}$ eccentricity $(\mathrm{e} / \mathrm{h}=1.0)$ which reduces the load capacity for the columns by $(0.00 \%, 0.66 \%, 2.65 \%, 4.97 \%$ and $11.26 \%)$ for hollowing ratios $(0 \%, 2.3 \%, 5.1 \%, 9 \%$ and $20.3 \%)$ respectively.
\end{abstract}

Keywords: long column; self-compact concrete; slender column; eccentricity; hole section

\section{Introduction}

To maximize structural efficiency in terms of strength/mass and stiffness/mass ratios and to reduce contribution of the column to seismic response and high carrying demand on foundation, it is desirable to use hollow cross section for columns. In location where the cost of concrete is relatively high, or in situations where the weight of concrete members is to be kept to a minimum, it may be economical to use hollow reinforced concrete columns.

Also, transverse openings and longitudinal holes are often provided in reinforced concrete columns to allow access for services such as pipes for plumbing and electric wiring. Few research studies exists regarding long columns and hollow columns especially when the columns are subjected to combined axial compression load and uniaxial bending moment. Many of the available research works deal with hollow reinforced concrete columns but under concentric load only, while other researchers studied the strength and behavior of hollow reinforced concrete bridge columns. The most notable investigations can be briefly summarized as follows:-

Bakhteri and Iskandar [1], carried out tests to investigate the effect of embedding rain water pipes inside reinforced concrete short columns in multistory buildings. Fourteen short columns in seven sets, having different sizes and reinforcement, with a PVC drain pipe positioned at the center of the cross section of each column have been tested.
Son et al. [2], 2006, carried out a test program on reinforced concrete short columns with transverse openings. Eight concrete columns with different transvers opening and one column without a hole were cast to evaluate the effect of section loss on the compressive resistance capacity. Two samples were cast for each type of column. The parameters examined experimentally were the diameter, relative position and number of holes.

Lignola et al. [3], carried out experimental tests on seven square hollow reinforced concrete short columns confined with CFRP. The cross section of the tested columns was $360 \times 360 \mathrm{~mm}$ with a wall thickness of $60 \mathrm{~mm}$. The longitudinal reinforcement was $16 \varnothing 10$ mm longitudinal bars with $25 \mathrm{~mm}$ concrete covers and $\varnothing 4 \mathrm{~mm}$ stirrups at $80 \mathrm{~mm}$ spacing

Galano and Vignoli [4], carried out a test on sixty high strength concrete and self-consolidation concrete slender columns. Each one was of a square cross section of $100 \mathrm{~mm}$ in dimensions and a length of $2000 \mathrm{~mm}$. Four different layouts of longitudinal and transversal reinforcements. Three values of concrete compressive strength were used $\left(f^{\prime} c=70,80\right.$ and $\left.100 \mathrm{MPa}\right)$. The columns were subjected to axial load with different eccentricities.

Yazici and Hadi [5], carried out a series of tests on the CFRP wrapped hollow core reinforced concrete circular short columns. In this study, eight circular short columns were divided into two groups (four columns denoted by (C) letter for externally unconfined and (L) letter for externally confined in the hoop direction by wrapping in three layers of lateral CFRP sheets). 
Campione et al [6], studied the behavior of fiber-reinforced concrete short columns subjected to concentrically compressive load An experimental study investigating sixteen short, confined, reinforced concrete column with and without steel fibers was conducted. The columns with a square cross section $\left(165^{*} 165\right) \mathrm{mm}$ at the mid-section were hunched at the ends to apply eccentric loading.

Müller et al.[7], studied the behavior ultra-high performance concrete spun slender columns under eccentric normal load. they tested 6 full-scale spun columns which were reinforced with high-strength steel bars of $670 \mathrm{MPa}$ yielding strength and $800 \mathrm{MPa}$ ultimate strength.

Fadhil [8], studied behavior of square hollow precast reactive powder concrete (RPC) short columns filled with ordinary concrete There are eighteen specimens with dimensions of $(180 \times 180 \times 400)$ $\mathrm{mm}$. The specimens are divided into two main groups, the first group contained nine specimens which were subjected to an eccentric load while the second group had nine specimens tested under mid-span lateral load.

From the previous studies it was found that many researches had been carried on the behavior of short columns. However. few of these researches deal with slender columns. Also, one can conclude that until now little experimental or analytical work has been done on the presence of longitudinal openings in columns. Therefore, the present work is devoted to study experimentally the reinforced concrete slender columns with longitudinal holes under eccentric loads. Also, different types of column length and some other important parameters of slender columns with hollow section will be investigated.

This study is devoted to investigate the behavior and load carrying capacity of slender and short columns having circular hole along column length. All columns were tested under eccentric load having different eccentricities. Concrete which has been used in this research was self-compacted concrete. Experimental tests were carried out in laboratory of Shatra Technical Institute and Engineering College structural lab of Thi-Qar University.

\section{Experimental program}

\section{2-1 Sample description}

Samples were ten slender columns. All samples had four different diameter holes $(0,1,1.5,2,3$ inch), where 1 inch is lesser than $04 \mathrm{Ag}$ for column section and 3 inch is greater circle to satisfy interior concrete cover. The columns were reinforced with $4 \varnothing 12$ deformed steel bars as main longitudinal reinforcement. Columns cross sectional area was $(150 * 150 \mathrm{~mm})$. Samples had brackets at both ends to make it possible to carry eccentric load. Fig (1) represents a typical sample with bracket shape.

In order to obtain accurate results of the effect of each of the mentioned parameters on the structural behavior and load carrying capacity of the column, a typical column must be considered with specified values for the parameters. The effect of using different values for one parameter was made possible by keeping the values of the remaining parameters constants.

For this purpose, the cross section shown of the reference column is considered which has

Effective length of column $(1300 \mathrm{~mm})$

The reference column and all other columns were reinforced with $12 \mathrm{~mm}$ longitudinal bars and $6 \mathrm{~mm}$ lateral ties, as explained in Table (1) .Table (2) shows dimensions of the columns.

Table 1: Details of the reference column reinforcement

\begin{tabular}{|l|l|l|}
\hline 1 & Longitudinal bars & $4 \phi 12 \mathrm{~mm}$ \\
\hline 2 & Ties & $\phi 6 @ 100 \mathrm{mmc} / \mathrm{c}$ \\
\hline 3 & Clear cover & $20 \mathrm{~mm}$ \\
\hline
\end{tabular}

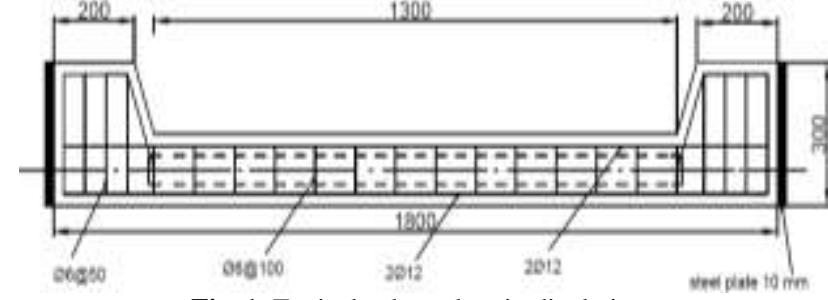

Fig. 1: Typical column longitudinal view

Table 2: Column dimensions and properties.

\begin{tabular}{|c|c|c|}
\hline \multicolumn{2}{|c}{ Table 2: Column dimensions and properties. } \\
\begin{tabular}{|c|c|c|}
\hline Columns & $\begin{array}{c}\text { Hollowing ratio } \\
(\%)\end{array}$ & Eccentricity e (mm) \\
\hline C1 & Solid section & 150 \\
\hline C2 & Solid section & 50 \\
\hline C3 & 2.3 & 150 \\
\hline C4 & 2.3 & 50 \\
\hline C5 & 5.1 & 50 \\
\hline C6 & 5.1 & 150 \\
\hline C7 & 9 & 150 \\
\hline C8 & 9 & 50 \\
\hline C9 & 20.3 & 150 \\
\hline C10 & 20.3 & 50 \\
\hline & & \\
\hline
\end{tabular}
\end{tabular}

\subsection{SCC Mix:}

The SCC mix was achieved according to EFNARC [9] to satisfy SCC fresh requirements of concrete properties. In the present work, the content of cement was $300 \mathrm{~kg} / \mathrm{m} 3$, content of fine aggregate was $797 \mathrm{~kg} / \mathrm{m} 3$, content of coarse aggregate was $767 \mathrm{~kg} / \mathrm{m} 3$, content of limestone powder was $170 \mathrm{~kg} / \mathrm{m} 3$, and water content was $190 \mathrm{l} / \mathrm{m} 3$. The super-plasticizer content was $4.91 / \mathrm{m} 3$ (1.4 liter per $100 \mathrm{~kg}$ of cement) and the w/p ratio was 0.36 . This mix satisfies all the limits recommended by EFNARC's mix design method.

\section{Hardened concrete properties}

Each batch was used to cast two column specimens, the compressive strength of concrete $\left(f^{\prime} c\right)$ was determined by testing two (150x $300 \mathrm{~mm})$ cylinders and four $(150 \times 150 \mathrm{~mm})$ cubes. The results of these tests are listed in Table (2). The considered value of concrete compressive strength for each batch was based on the average values of the specimens. The modulus of elasticity was predicted following the ACI $318 \mathrm{M}-14$ expression.

paragraphs must be justified alignment. With justified alignment, both sides of the paragraph are straight.

Table 3: Concrete material properties of tested columns.

\begin{tabular}{|c|c|c|c|}
\hline Columns & $\begin{array}{c}\text { Cylindrical } \\
\text { Compression } \\
\text { strength (MPa) }\end{array}$ & $\begin{array}{c}\text { Modulus of } \\
\text { Elasticity } \\
(\mathrm{MPa})\end{array}$ & $\begin{array}{c}\text { Cube compres- } \\
\text { sion strength } \\
(\mathrm{MPa})\end{array}$ \\
\hline C1,C2 & 42.1 & 30496 & 51.5 \\
\hline C3,C4 & 40.8 & 30021 & 49.7 \\
\hline C5,C6 & 41.2 & 30168 & 50.2 \\
\hline C7,C8 & 40.6 & 29948 & 49.6 \\
\hline C9,C10 & 41.1 & 30131 & 49.6 \\
\hline
\end{tabular}

\section{Test measurement and instrumentations}

\subsection{Measurement of lateral deflection}

Three dial gauges were fixed to measure the lateral deflection for each column specimen at each loading stage. The dial gauge had an accuracy of $0.01 \mathrm{~mm}$. The dial gauges were symmetrically placed on the surface of the column at the positions shown in Fig. (2). The average reading of top and bottom dial gauges has been subtracted from the reading of the middle dial gauge to obtain the net lateral deformation $(\Delta)$ of the tested column. This procedure was repeated for every loading stage. . 


\subsection{Measurement of vertical deflection}

One dial gauge was fixed to measure the vertical deflection for each specimen at every loading stage. The dial gauge was identical to the dial gauges used to measure the lateral deflection. Fig. (2) shows location of the vertical dial gauge.

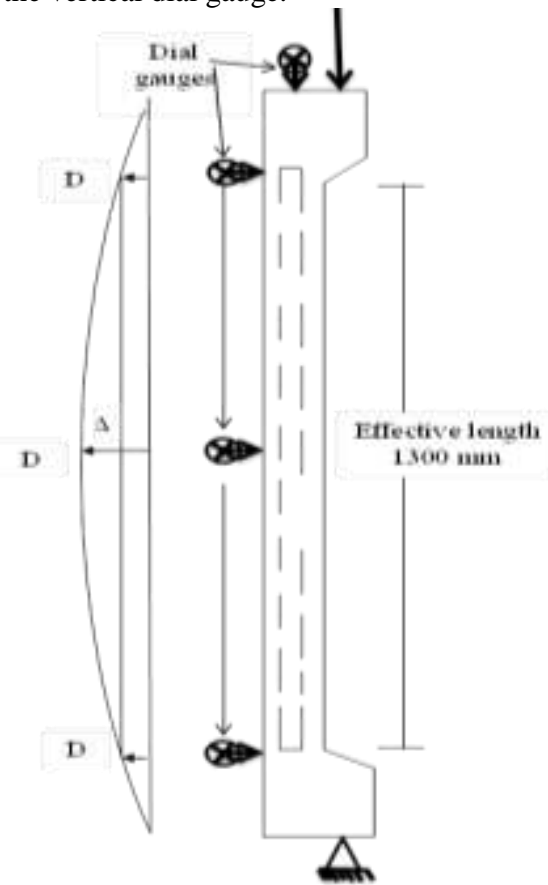

Fig. 2: Setup and locations of dial gauges for the tested columns.

Loading was applied monotonically using a universal testing machine which has a hydraulic jack with a maximum capacity of 600 $\mathrm{kN}$. Column specimens were tested vertically, the load was applied on the top end of the column at 50 or $150 \mathrm{~mm}$ eccentricity, while the other end was positioned to the frame by a pin ended support and has same eccentricity of the top end to insure the same value of moment along column length.

\section{Effect of hole diameters on the tested column}

\subsection{Tested slender columns under $150 \mathrm{~mm}$ eccentric loading}

This section deals with the effect of using different hollowing ratio of columns on the values of the load carrying capacity and midheight lateral deflection and longitudinal shortening of columns under eccentric loading at $150 \mathrm{~mm}$ eccentricity. Five values of hollowing ratio were considered $(0.00 \%$ solid, $2.3 \%, 5.1 \%, 9 \%$, $20.3 \%)$. The diameters of the holes were (0.00 solid, 25.4, 50.8, $38.1,76.2) \mathrm{mm}$ respectively. The five considered columns had the same properties of the reference column ( material and geometric aspects). The considered variable was the hollowing ratio only. The five specimens were characterized by the formation of cracks at the tension face then increasing stress in tension reinforcement and shifting the neutral axis towards the compression zone

Table (4) shows cracking and ultimate loads of columns (C1,C3,C6,C7 and C9). Fig. (3) and (4) exhibit the effect of hollowing ratio on ultimate load and cracking load values respectively. Figs. (5) and (6) deal with the effect of vertical load on lateral deflection at mid height of the column and column longitudinal shortening respectively. Figs. (7) and (8), present the effect of hollowing ratio on the maximum lateral deflection at mid-height of columns at ultimate load stage and the maximum column longitudinal shortening respectively. Plate (1) (a) represents failure mode for columns under $150 \mathrm{~mm}$ loaded.

The holes at center of the columns cross-section and the columns were loaded with high load eccentricity, that means that the section was loaded by a high moment, the high moment results in small compression area in the compression side and cracked wide area of column cross section. It is worth to say that the similarity in the behavior of the columns of this group is because of the high load eccentricity of $150 \mathrm{~mm}$. All columns of this group have a tension failure mode and the effect of holes may be insignificant since it is mainly located in the tension area of the column section, this fact makes the effect of hollowing ratio on load capacity insignificant. For hollowing ratios used in this study $(0 \%, 2.3 \%, 5.1 \%, 9 \%$ and $20.3 \%)$, ultimate load was decreased by $(0 \%, 0.28 \%, 1.03 \%, 3.28 \%$ and $6.48 \%$ ) respectively.

Table 4: Cracking and ultimate loads of columns of group one (C1,C3,C6,C7,C9)

\begin{tabular}{|c|c|c|c|c|}
\hline $\begin{array}{c}\text { Col- } \\
\text { umns }\end{array}$ & $\begin{array}{c}\text { Hollow ratio } \\
\text { (H.R.) } \\
\%\end{array}$ & $\begin{array}{c}\text { First crack- } \\
\text { ing load } \mathrm{P}_{\text {cr }} \\
(\mathrm{kN})\end{array}$ & $\begin{array}{c}\text { Ultimate } \\
\text { load } \\
\mathrm{P}_{\mathrm{u}}(\mathrm{kN})\end{array}$ & $\begin{array}{c}\text { decreasing } \\
\text { in }\left(\mathrm{P}_{\mathrm{u}}\right) \%\end{array}$ \\
\hline $\mathrm{C} 1$ & 0 & 23 & 106.5 & 0.00 \\
\hline $\mathrm{C} 3$ & 2.3 & 23 & 106.2 & 0.28 \\
\hline $\mathrm{C} 6$ & 5.1 & 22.9 & 105.4 & 1.03 \\
\hline $\mathrm{C} 7$ & 9 & 22.5 & 103 & 3.28 \\
\hline $\mathrm{C} 9$ & 20.3 & 20 & 99.6 & 6.48 \\
\hline
\end{tabular}

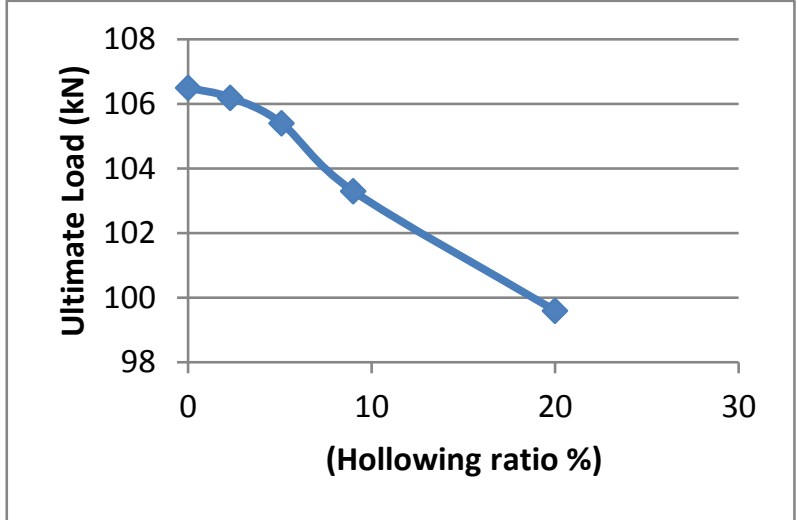

Fig. 3: Effect of hollowing ratio on ultimate load.

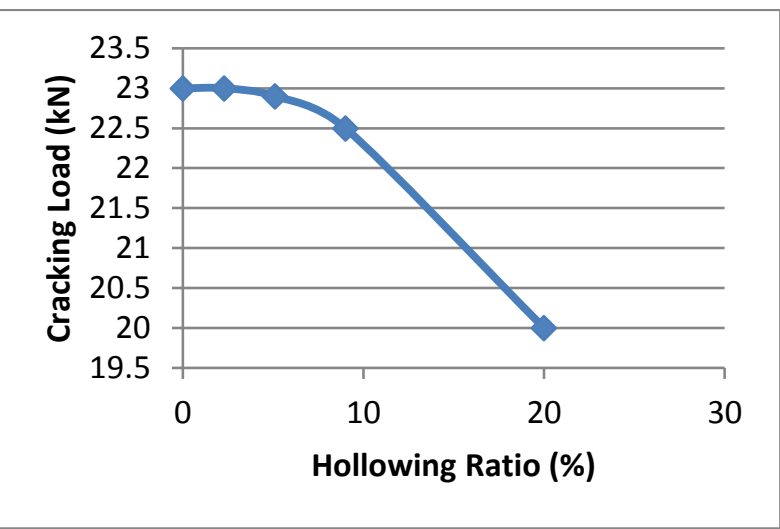

Fig. 4: Effect of hollowing ratio on Cracking load.

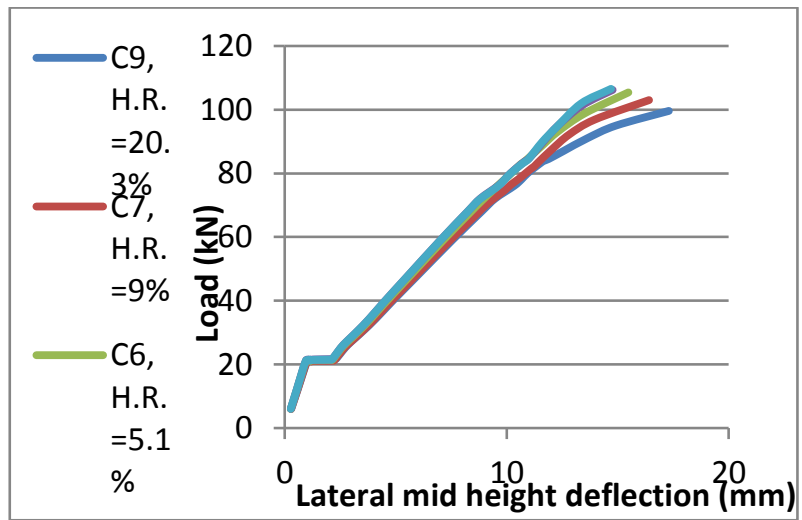

Fig. 5: Effect of vertical load on lateral deflection at mid height of group one columns. 


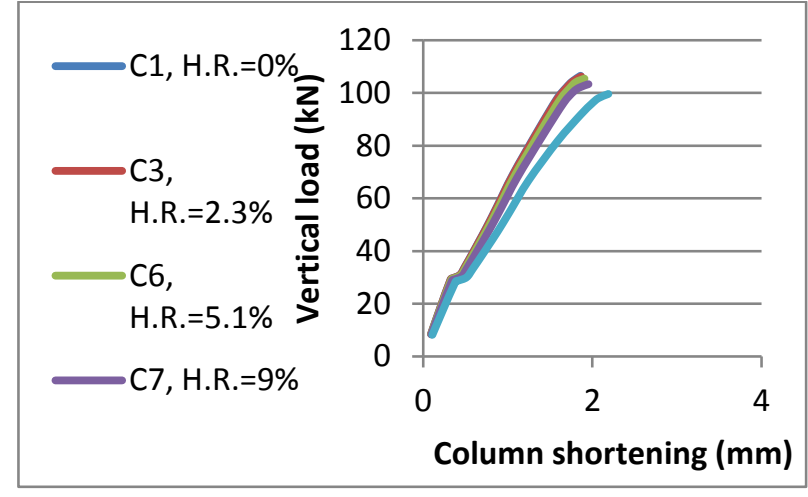

Fig. 6: Effect of vertical load on column longitudinal shortening of group one columns

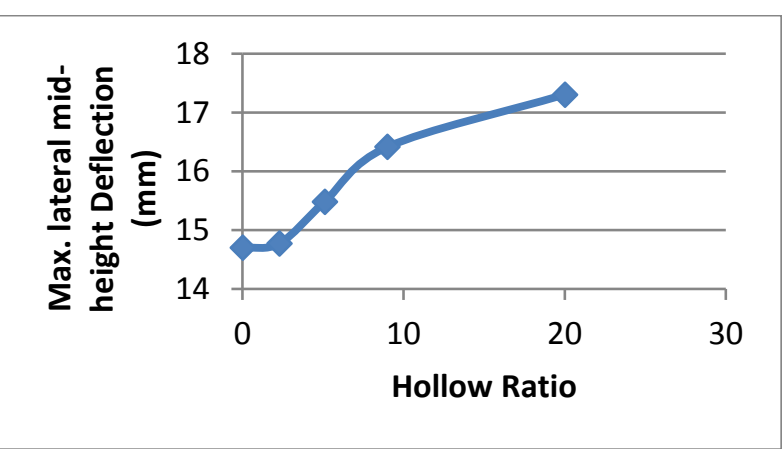

Fig. 7: Effect of hollowing ratio on max. lateral deflection at mid-height of columns at ultimate load of group one columns.

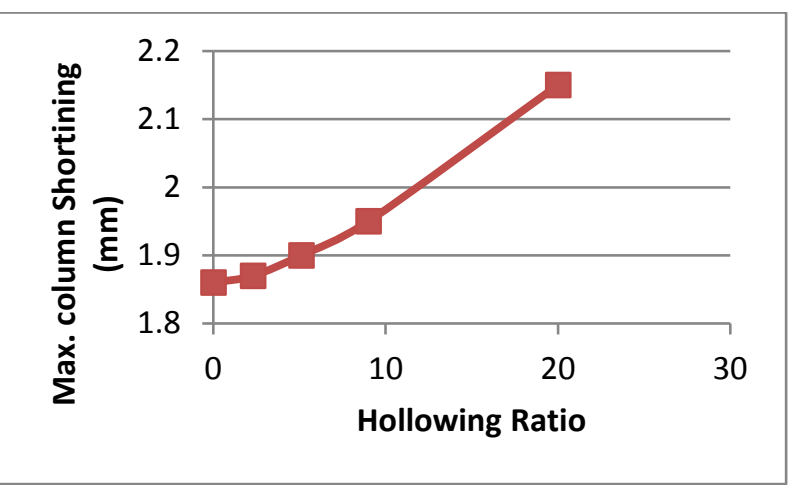

Fig. 8: Effect of hollowing ratio on max. column longitudinal shortening for group one columns.

\subsection{Tested slender columns under $50 \mathrm{~mm}$ eccentric load- ing}

This section deals with eccentric loading of $50 \mathrm{~mm}$ eccentricity. Five types of hollowing ratios were considered $(0.00 \%, 2.3 \%, 5.1 \%$, $9 \%$, and $20.3 \%)$. The diameter of holes were $(0.00,25.4,50.8,38.1$ and 76.2)mm respectively. The five tested columns had the same properties of the reference column ( material and geometric aspects), the variable was hollowing ratio only.

Table (5) represents cracking and ultimate loads of the tested columns (C2, C4, C5, C8 and C10). Figs. (9) and (10) show the effect of hollowing ratio on the ultimate and cracking loads values respectively. Figs. (11) and (12) represent the effect of vertical load on lateral deflection at mid height of columns and column longitudinal shortening respectively. Figs. (13) and (14) represent effect of the hollowing ratio on max. lateral deflection at mid-height of columns at ultimate load level. and max. columns longitudinal shortening respectively. Plate (1) (b,c,d)) represent failure mode for columns under $150 \mathrm{~mm}$ loaded. For this group of columns, the eccentricity of load is small but because the columns is specified as long ( slender) columns according to ACI Code, 318-14 provisions, the five specimens were characterized by the formation of cracks at the tension face then shifting the neutral axis towards the compression zone.
The effect of hollowing ratio on columns loaded with small eccentricity $(\mathrm{e} / \mathrm{h}=.33)$ greater than the effect of hollowing ratio of columns with $150 \mathrm{~mm}$ eccentricity discussed in section (4-4-1) because most of column cross section was stressed by compression load. In this case the holes are out of cracking part of the cross section, which reduces load capacity for the columns in group two, the reduction values of the ultimate load are $(0.00 \%, 0.66 \%, 2.65 \%$, $4.97 \%$ and $11.26 \%)$ for hollowing ratios $(0 \%, 2.3 \%, 5.1 \%, 9 \%$ and $20.3 \%$ ) respectively, The tensile longitudinal steel bars in all spacemen had small values of stress up to (100) $\mathrm{kN}$ load level since the dominant mode of failure is the compression mode. Generally the first crack was appeared at column tension face at high load level because the dominant factor is the applied compressive rather than the bending moment.

Table 5: Cracking and ultimate loads of tested columns (C2,C4,C5,C8 and C10).

\begin{tabular}{|l|l|l|l|l|}
\hline Columns & $\begin{array}{l}\text { Hollow } \\
\text { ratio } \\
(\text { H.R. }) \\
\%\end{array}$ & $\begin{array}{l}\text { First crack- } \\
\text { ing load } \mathrm{P}_{\text {cr }} \\
(\mathrm{kN})\end{array}$ & $\begin{array}{l}\text { Ultimate } \\
\text { load } \\
\mathrm{P}_{\mathrm{u}}(\mathrm{kN})\end{array}$ & $\begin{array}{l}\text { decreasing in } \\
\left(\mathrm{P}_{\mathrm{u}}\right) \%\end{array}$ \\
\hline C2 & 0 & 142 & 302 & 0.00 \\
\hline C4 & 2.3 & 140 & 300 & 0.66 \\
\hline C5 & 5.1 & 135 & 294 & 2.65 \\
\hline C8 & 9 & 129 & 287 & 4.97 \\
\hline C10 & 20.3 & 113 & 268 & 11.26 \\
\hline
\end{tabular}

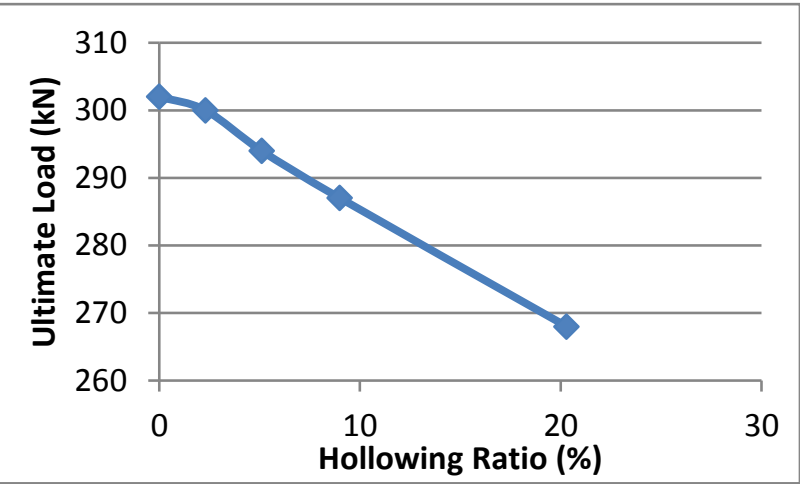

Fig. 9: Effect of hollowing ratio on ultimate load of columns of group two.

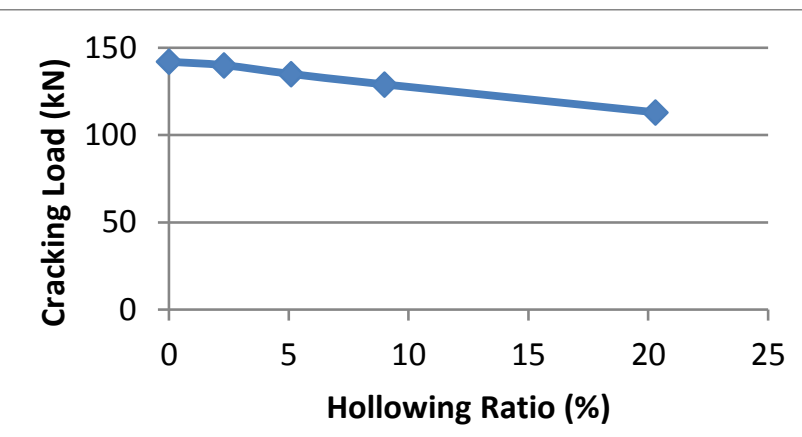

Fig. 10: Effect of hollowing ratio on cracking load of columns of group two.

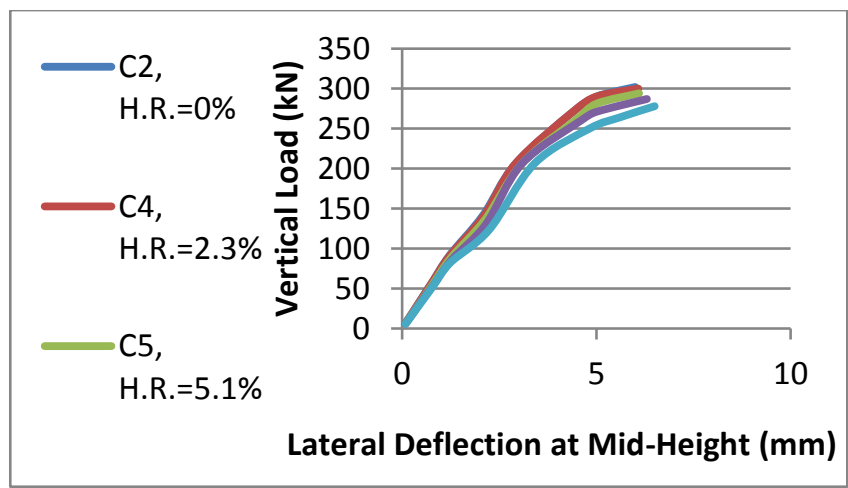

Fig. 11: Effect of vertical compressive load on lateral deflection at mid height of columns of group two. 


$$
\begin{aligned}
& \mathrm{C} 2, \mathrm{H} . \mathrm{R} .= \\
& 0 \% \\
& \mathrm{C} 4, \mathrm{H} . \mathrm{R} .= \\
& 2.3 \% \\
& \mathrm{C} 5, \mathrm{H} . \mathrm{R} .= \\
& 5.1 \% \\
& \mathrm{C} 8, \mathrm{H} . \mathrm{R} .= \\
& 9 \% \\
& \mathrm{C} 10, \mathrm{H} . \mathrm{R} .= \\
& 20.3 \%
\end{aligned}
$$

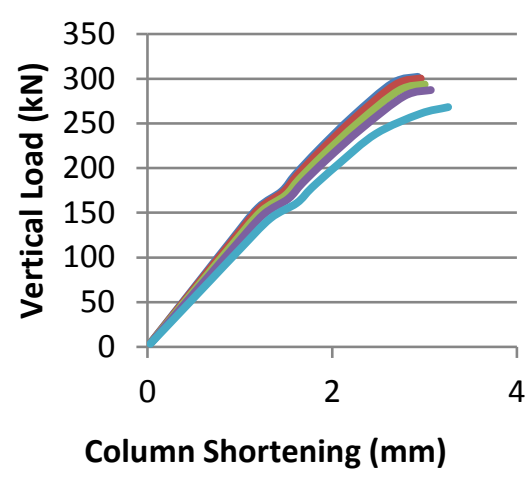

Fig. 12: Effect of vertical compression load on longitudinal shortening of columns of group two

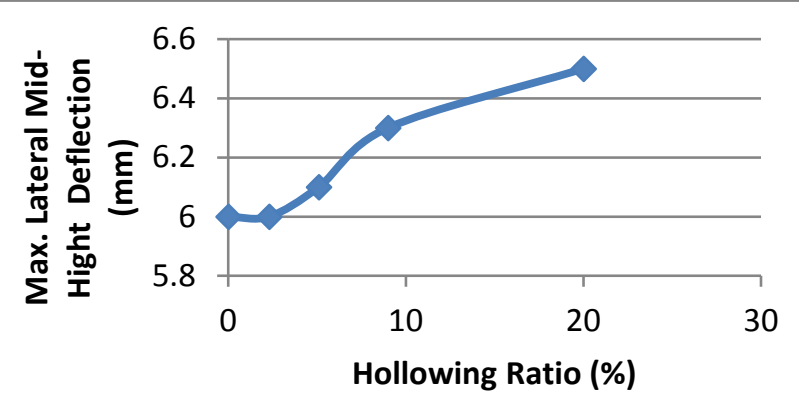

Fig. 13: Effect of hollowing ratio on max. lateral deflection at mid height of columns of group two

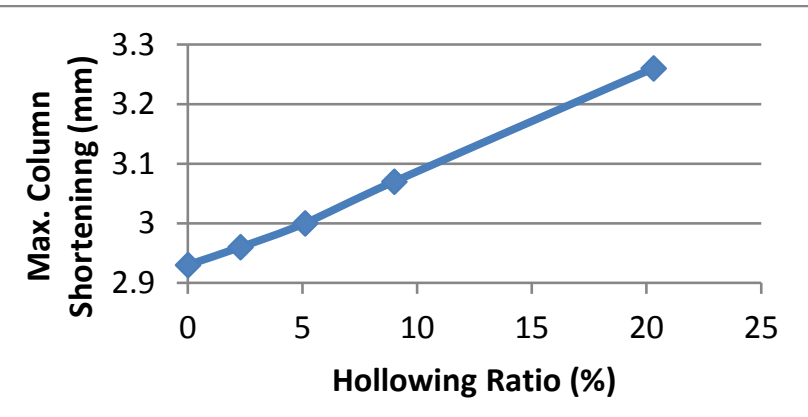

Fig. 14: Effect of hollowing ratio on max. longitudinal shortening of columns of group two

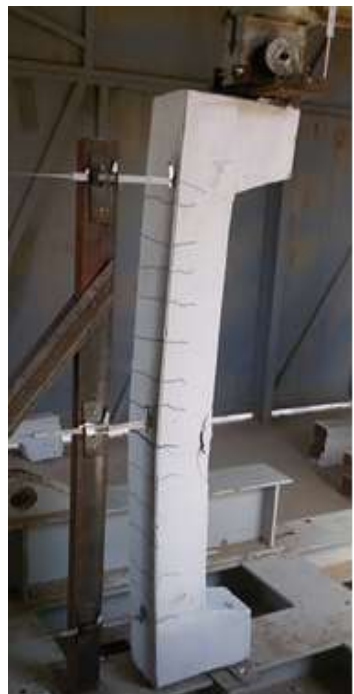

(a)

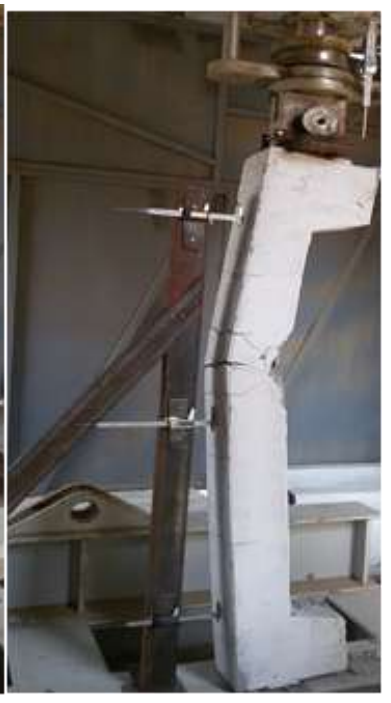

(b)

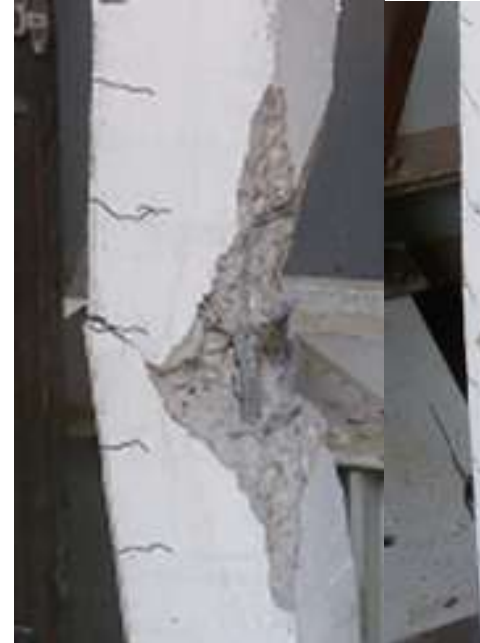

(c)

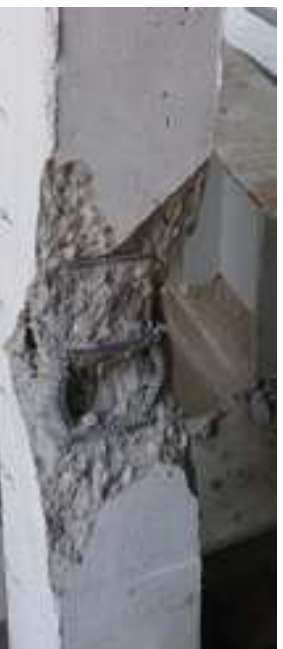

(d)

Plate 1: Failure mode for tested columns ((a) Under $150 \mathrm{~mm}$ loaded and (b,c,d)Under $50 \mathrm{~mm}$ loaded )

\section{Conclusion}

1.The presence of circular longitudinal hole in reinforced concrete slender columns significantly reduces its ultimate load capacity. For $(e / h=.33)$, the experimental results indicate reduction ranges in strength of $(2.7 \%$ to $11.3 \%)$. These ranges of strength reduction correspond to a range of $(5.1 \%-20.3 \%)$ of hollowing ratio.

2. For higher ratios of $(e / h=1.0)$, the experimental results showed that when the hollowing ratio was increased, no considerable change in the ultimate loads occurred.

3.The columns with higher ratios of $(e / h=1.0)$ of this group had a tension failure mode and the effect of holes may be insignificant since they are mainly located in the tension area of the column cross section. For small ratios of $(e / h=0.33)$, the columns had a compression failure mode.

\section{References}

[1] Bakhteri, J. and Iskandar, S. A.," Experimental Study of Reinforced Concrete Columns Concealing Rain Water Pipe" Jurnal Teknologi, Vol. 43(B), December 2005, pp. 13-26.

[2] Son, K. S.; Pilakoutas, K. and Neocleous, K.," Behaviour of Concrete Columns with Drilled Holes" Magazine of Concrete Research, Vol. 58, No. 7, September 2006, pp. 411-419.

[3] Lignola, G. P.; Porta, A.; Manfredi, G. and Cosenza, E., "Experimental Performance of RC Hollow Columns Confined with CFRP", Journal of Composites for Construction, ASCE, Vol. 11, No. 1, January-February 2007, pp. 42-49.

[4] Galano, L. and Vignoli, A.," Strength and Ductility of HSC and SCC Slender Columns Subjected to Short-Term Eccentric Load", ACI Structural Journal, Vol. 105, No. 3, May- June 2008, pp. 259-269.

[5] Yazici, V. and Hadi, M. N. S.," Axial Load-Bending Moment Diagram of Carbon FRP Wrapped Hollow Core Reinforced Concrete Columns" Journal of Composites for Construction, ASCE, Vol. 13 No. 4, August 2009, pp. 262-268.

[6] Campione G., Fossetti, M.,Papia M., " Behavior Fiber -Reinforced Concrete Columns under Eccentrically Compressive Load" ACI Structural Journal, Vol.107, No. 3, May -June 2010, pp. 272-280.

[7] Müller, C.; Empelmann, M.; Lieb, H.; and Hude, F., "Ultra-High Performance Spun Concrete Columns with High-Strength Reinforcement," Proceedings of the 3P rd P International Symposium on UHPC and Nanotechnology for High Performance Construction Materials, Kassel, Germany, March 7-9, pp. 733-740, 2015

[8] Fadhil "Experimental Investigation of Hollow Square Reactive Powder Concrete Columns Filled with Normal Concrete " M.Sc. Thesis, University of Technology, 2017, pp. 144.

[9] EFNARC: European Federation Dedicated to Specialist Construction Chemicals and Concrete Systems, 2002,"Specifications and Guidelines for Self-Compacting

[10] Concrete", Association House, 99 West Street, Farnham, Surrey, U.K, pp.32. 